\section{In vitro antitrypanosomal potential of chloroform leaf extract of Punica granatum L. on Trypanosoma brucei brucei and Trypanosoma evansi}

\author{
Muhammad Muhsin Fathuddin, ${ }^{1}$ \\ Helen Ileigo Inabo ${ }^{2}$
}

${ }^{1}$ Department of Microbiology, Kaduna State University, Kaduna; ${ }^{2}$ Department of Microbiology, Faculty of Science, Ahmadu Bello University, Zaria, Nigeria

\begin{abstract}
The plant Pomegranate (Punica granatum Linn.) selected for this study is native to the region of Eurasia. The objective of this study was to evaluate the antitrypanosomal potential of the plant against Trypanosoma brucei brucei (T.b. brucei) and Trypanosoma evansi (T. evansi). Similarly, the parasites used for this study have two entirely different modes of transmission that is Cyclical Transmission (T.b. brucei) and Mechanical Transmission (T. evansi). The chloroform extract of Punica granatum (P. granatum) was analysed in vitro for trypanocidal activity against T.b. brucei and T. evansi at concentrations of $100 \mathrm{mg} / \mathrm{mL}, 50 \mathrm{mg} / \mathrm{mL}, 25$ $\mathrm{mg} / \mathrm{mL}, 12.5 \mathrm{mg} / \mathrm{mL}$ and $6.25 \mathrm{mg} / \mathrm{mL}$. The chloroform extracts of $P$. granatum had trypanocidal activity against $T$. evansi and was inactive against T.b. brucei. These findings suggest that the mode of transmission may have an effect on the parasite-drug reaction and the possible use of the chloroform extract of $P$. granatum in the management of trypanosomiasis due to $T$. evansi which may require further elucidation.
\end{abstract}

\section{Introduction}

Trypanosomosis is one of the major obstacles for livestock production in Africa,${ }^{1}$ and continues to cause morbidity and mortality on a large scale in the world. ${ }^{2}$ The trypanosomes had been first reported to occur in trouts (Valentine, 1841) and frogs (Gluge, 1842), ${ }^{3}$ but it was not until 1881 that Griffith Evans found trypanosomes in the blood of horses and camels with a wasting disease called Surra and suggested that the parasites might be the cause of this disease. ${ }^{4}$ In 1895, the Scottish Pathologist and Microbiologist David Bruce (1855-1931) discovered Trypanosoma brucei as the cause of cattle nagana (cattle Trypanosomiasis). ${ }^{5}$
Surra is widespread in different parts of the world and poses a major constraint to camel productivity. ${ }^{6}$ Surra is endemic and its geographical distribution is continuous from the northern part of Africa through the Middle East to South-East Asia. ${ }^{7}$ The Parasite is transmitted through mechanical transmission by Tabanid striatus flies, similar to the transmission of parasites in animals. ${ }^{8}$

African animal trypanosomiasis was initially thought to be transmitted mechanically by tsetse flies. However, it was the German military surgeon Friedrich Karl Kleine (1869-1951) who showed in 1909 the cyclical transmission of T.b. brucei in tsetse flies. ${ }^{5} T$. b. brucei, the causative agent of nagana, is closely related to Trypanosoma brucei rhodesiense (East to South of Africa) and Trypanosoma brucei gambiense (West and Central Africa) which cause human African trypanosomiasis, or sleeping sickness. ${ }^{3}$ The distribution of trypanosomiasis in Africa corresponds to the range of tsetse flies and comprises currently an area of 8 million $\mathrm{km}^{2}$ between 14 degrees North and 20 degrees South latitude. ${ }^{5}$ It is difficult to estimate the overall burden of African trypanosomiasis because of under diagnosis in the most heavily infected countries. However, it is believed to be in the vicinity of 100,000 new cases per year, with between $1 / 3$ and $1 / 2$ of cases remaining undetected and untreated..$^{9,10}$

However, the efficiency of the drugs available is limited by a number of features, which include increasing parasite resistance ${ }^{11}$, treatment failures, undesirable toxicity, ${ }^{12,13}$ unavailability, logistics of administration, long period of treatment, and high cost. ${ }^{14}$ In the pursuit for novel trypanocides, an extensive variety of medicinal plants have been nominated for antitrypanosomal activity and reasonable quantity of them has been stated to have noteworthy antitrypanosomal activity. 9,15,16 Several secondary plant metabolites including alkaloids, tannins and anthraquinones have been designated with trypanocidal activity. ${ }^{17}$ Plants have been reported to be the foundation of traditional treatment for various types of disorders. ${ }^{6,15,18,19}$ Nevertheless, there have been lately numerous reports on the assessment of the antitrypanosomal properties of plant extracts and plant derivatives. $2,18,20-24$

Punica granatum L., commonly recognized as the pomegranate, belongs to the family Punicaceae which comprises only one genus and two species, the other one, little-known, being P. protopunica (Balf.) peculiar to the island of Socotra. The pomegranate is another extensively exploited fruits for food, juice, flavour, fragrance and colour. The fruit was used in countless
Correspondence: Muhammad Muhsin Fathuddin, Department of Microbiology, Kaduna State University, Kaduna, Nigeria. Tel.: +234.8085.350964.

E-mail: muhsinfathuddin@gmail.com

Key words: Antitrypanosomal activity, Trypanosoma brucei brucei, Trypanosoma evansi, Punica granatum, Chloroform.

Acknowledgments: the authors wish to thank the staffs of National Research Institute for Chemical Technology (NARICT), Basawa, Zaria for their cooperation and assistance during the experiments.

Contributions: the authors contributed equally.

Conflict of interest: the authors declare no potential conflict of interest.

Received for publication: 12 November 2016. Revision received: 12 March 2017.

Accepted for publication: 30 March 2017.

This work is licensed under a Creative Commons Attribution NonCommercial 4.0 License (CC BY-NC 4.0).

(C) Copyright M.M. Fathuddin and H.I. Inabo, 2017 Licensee PAGEPress, Italy

Microbiology Research 2017; 8:6963

doi:10.4081/mr.2017.6963

ways as it is today and was featured in Egyptian mythology and art, acclaimed in the Old Testament of the Bible and in the Babylonian Talmud, and it was carried by desert caravans for the sake of its thirstquenching juice. $^{25}$

The plant has been used in several research studies for its properties such as antibacterial, ${ }^{26,27}$ anticancer, ${ }^{28-30}$ antidiarrhoeal, ${ }^{31}$ antifungal, ${ }^{22}$ antihelminthic, ${ }^{30,32,33}$ antimalarial, ${ }^{34-36}$, andantioxidant properties. $^{37}$ It is suggested that there is a significant link between cancer and trypanosomiasis chemotherapies. ${ }^{9,38}$

\section{Materials and Methods}

\section{Sample preparation and extraction}

The fresh leaves of Punica granatum were collected from Area BZ of Main Campus of Ahmadu Bello University, in Samaru, Zaria. They were authenticated at the Herbarium, Department of Biological Science, Ahmadu Bello University, Zaria; was given a voucher no. 1917. The leaves were air-dried at Room Temperature; then, were subjected to powdering which was then being subjected to the Soxhlet extrac- 
tion method (also known as hot percolation) with Chloroform solvent. The extracted analytes was concentrated by distilling off the excess solvent. ${ }^{39}$

\section{Phytochemical screening}

Standard protocols to identify the constituents were carried out to test for the presence of alkaloids, flavonoids, glycosides, resins, saponins and tannins. ${ }^{39}$

\section{Preparation of extract dosages}

To produce a stock solution of 100 $\mathrm{mg} / \mathrm{mL}$ for the extract, weighed 1 gram $(1000 \mathrm{mg})$ of the extract which were solubilised in $1 \mathrm{~mL}$ of dimethylsulfoxide (DMSO) solution and made up to $10 \mathrm{mLin}$ Dextrose saline. Serial dilutions were made for the $50,25,12.5$ and $6.25 \mathrm{mg} / \mathrm{ml}$ concentrations of the extracts. All subsequent dilutions were made in Dextrose saline and were freshly prepared. ${ }^{40}$

\section{Laboratory animals}

Wister strain albino rats were used for the in vitro analysis were obtained and kept in the animal house of National Research Institute for Chemical Technology, Basawa, Zaria. The animals were kept under wellventilated conditions, fed on standard Feeds (Excel Feeds PLC.) throughout the course of the experiment and had access to clean and fresh water ad-libitum. The experimental animals were handled in accordance with: i) Good Laboratory Practices for Quality Practices for Regulated NonClinical Research and Development (World Health Organization) $)^{41}$; ii) CPCSEA Guidelines for Laboratory Animal Facility [the Committee for the Purpose of Control and Supervision of Experiments on Animals (CPCSEA) $]^{42}$; iii) Animal Use and Care Policy in the Research Policy [Ahmadu Bello University Committee on Animal Use and Care (ABUCAUC) $]^{43}$

This experimental work had the approval of the Ahmadu Bello University Committee on Animal Use and Care (ABUCAUC) (Approval No. ABUCAUC/2012/MICROB/APP/001).

The experimental animals were screened for any ailment at the Faculty of Veterinary Medicine's Parasitology Laboratory at the commencement of the experiment using the laboratory's recommended procedure and were cleared of any ailment.

\section{Test organisms}

T. b. brucei and T. evansi was obtained from National Research Institute for Chemical Technology (NARICT), Basawa, Zaria. The parasites were maintained in the laboratory by continuous passage in rats. Blood from the tail was used as estimation of parasitaemia. ${ }^{17}$

\section{In vitro test for trypanocidal activity}

The trypanosome parasitaemia was determined by the use of wet mount, according to the Wet and Thick Blood Film method, ${ }^{44}$ and microscopic evaluation at $400 \times$ magnification using the Rapid Matching method. ${ }^{45}$ Assessment of the in vitro trypanocidal activity was performed in duplicate in 96 round bottom well microtitre plates. The infected rat to undergo euthanasia must have attained a blood parasitaemia of $\log 8.4$ or higher. ${ }^{45}$ Euthanatized animal's blood was dissolved in heparin (1 $\mathrm{mL}$ of heparin/10 mL of blood) and was mixed with glucose ( $0.1 \mathrm{gm}$ of glucose/10 $\mathrm{mL}$ of blood). Then, have aseptically been using a clean micropipette to transfer the blood $(50 \mu \mathrm{L})$ to a clean, sterile micro-titre plate into a multiple number of well. To the well containing blood, same volume of the drug/extracts (i.e. $50 \mu \mathrm{L}$ ) was added of dif- ferent concentrations respectively. The negative control blood was mixed with dextrose saline. The plates were incubated at room temperature. ${ }^{17,40}$ For reference, positive tests were also performed with the standard recommended concentrations of Diminazine aceturate (Sequene, PI Drugs and Pharmaceuticals Ltd, India, and Diminor plus Changzhou Animal Health Products Co. Ltd, China) - a commercially available trypanocidal drug.

\section{Results}

The results in the chloroform extraction were found a Dark Green Residue and Percentage yield obtained was 11.80 $(\% \mathrm{~W} / \mathrm{W})$. The phytochemical screening results are shown in Table 1. The phytoconstituents of $P$. granatum include Carbohydrates and Glycoside. The in vitro analysis results for the extract are shown in Figure 1 and 2. The chloroform extract did not have any activity on the T.b. brucei even at $100 \mathrm{mg} / \mathrm{mL}$ the parasite remained viable

Table 1. Phytochemical screening of chloroform extract of Punica granatum L.

Constituents Chloroform extract

Alkaloids

Carbohydrates +

Tannins

Saponin -

Flavonoids

Terpenes -

Glycosides +

Cardiac glycosides + +/-

Anthraquinone

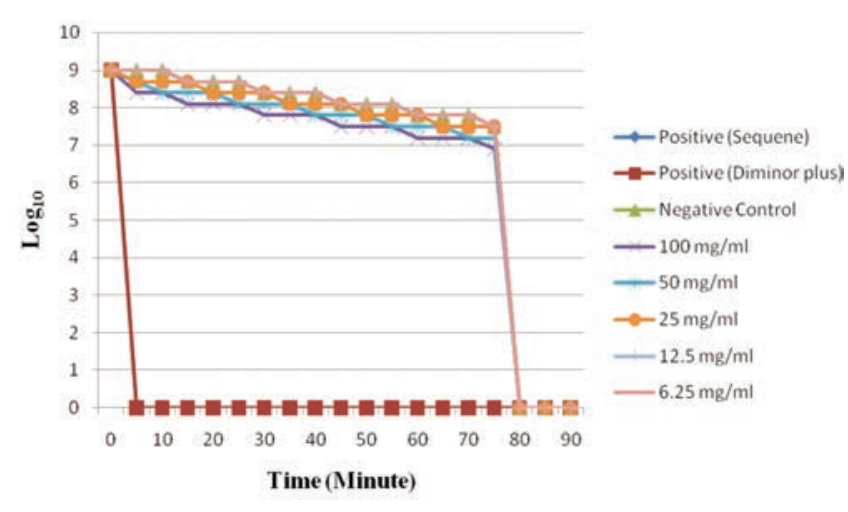

Figure 1. Chloroform Extract of Punica granatum L. against Trypanosoma brucei brucei.

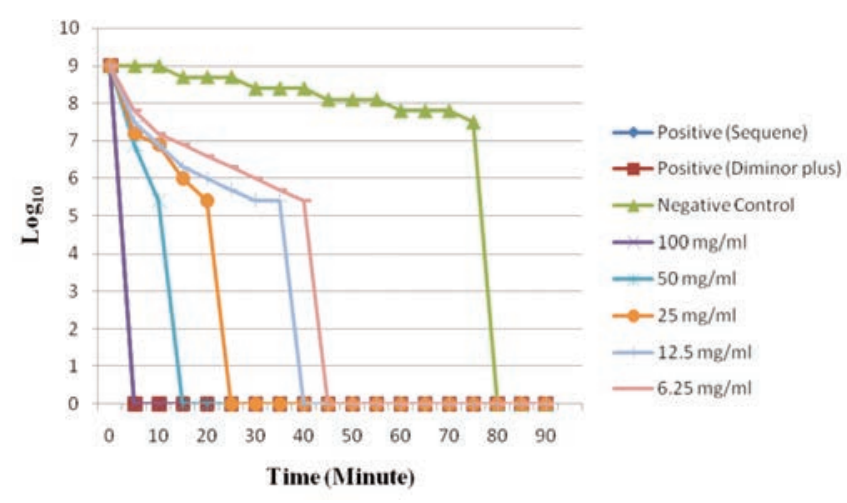

Figure 2. Chloroform Extract of Punica granatum L. against Trypanosoma evansi. 
though the red blood cells were lysed, the parasite motility cleared in the negative control. However, the chloroform extract had antitrypanosomal activity on $T$. evansi although between $6.25-100 \mathrm{mg} / \mathrm{mL}$, the red blood cells were still intact and the parasite motility increased with a reduction in concentration. After 50 minutes, the motility of the parasite was eliminated even though in the negative control the parasite motility continued for up to 80 minutes. The positive control involving two commercial trypanocidal drugs which were prepared to standard specifications cleared the parasite in less than 5 minutes (about 3 minutes) but it lysed the red cell.

\section{Discussion and Conclusions}

The result of the present study showed that the plant had activity against $T$. evansi and was inactive against T.b. brucei may be due to the absence of alkaloids and flavonoids in the crude extract. ${ }^{46,47}$ This finding suggests that the mode of transmission may have an effect on the parasite-drug interaction. It is thus possible for any plants that did not show activity to a species of the parasite, thus can have activity against other species of the parasites. ${ }^{1,40}$ Moreover, the result suggestive and similar with that reports that some plants had promising activity against trypanosomes. ${ }^{2,15,20,48,49}$ The morphology of the blood cells was maintained while that of the parasites was affected when compared to the control that still had very active parasites. The mechanism by which the extracts eliminate/immobilize the parasites is not immediately known at this stage of the work. ${ }^{50}$

\section{References}

1. Wurochekke AU, Nok AJ. In vitro antitrypanosomal activity of some medicinal plants used in the treatment of trypanosomosis in Northern Nigeria. Afr J Biotechnol 2004;3:481-3.

2. Hoet S, Opperdoes F, Brun R, et al. In vitro antitrypanosomal activity of ethnopharmacologically selected beninese plants. J Ethnopharmacol 2004;91: 37-42.

3. Raadt PD. The history of sleeping sickness. World Health Organization. 2005. Available from: http://www.who.int/trypanosomiasis_african/country/history/e $\mathrm{n} /$ print.html

4. Cox FEG. History of human parasitology. Clin Microbiol Rev 2002;15:595612.
5. Steverding D. The history of African trypanosomiasis. Parasites Vectors 2008;1:3.

6. Adeiza AA, Maikai VA, Hassan FB. Phytochemical screening and evaluation of some medicinal plants for their in vitro activities on Trypanosoma evansi. J Med Plants Res 2009;3:315-8.

7. Desquesnes M, Dargantes A, Lai DH, et al. Trypanosoma evansi and Surra: a review and perspectives on transmission, epidemiology and control, impact, and zoonotic aspects. BioMed Res Int 2013;2013:1-20.

8. Joshi PP. Human trypanosomiasis in India: is it an emerging new zoonosis? 2013. Available from: http://www.apiindia.org/medicine update_2013/chap04. pdf

9. Abdulkadir A, Mgbojikwe LO, Iliyasu B, et al. Anti-trypanosomal potential of Momordica balsamina linn fruit pulp extract against Trypanosoma brucei brucei infection. Afr $\mathrm{J}$ Infect Dis 2006;1:42-51.

10. Pépin J, Méda H. The epidemiology and control of human African trypanosomiasis. Adv Parasitol 2001;49:71-132.

11. Afewerk Y, Clausen PH, Abebe G, et al. Multiple-drug resistant trypanosoma congolense populations in village cattle of Metekel District, North-West Ethiopia. Actatropica 2000;76:231-8.

12. Onyekwelu NA. Toxicity of existing trypanocides: a review. West Afr J Pharmacol Drug Res 1999;15:1-6.

13. Triolo N. A case of coma due to arsobal in a newborn affected with congenital Trypanosomiasis gambiense. Ther Infect Dis 1990;5:165-6.

14. Don R, Chatelain E. Drug discovery for neglected diseases: view of a public-private partnership. In: Paul MS, Ed. Antiparasititc and antibacterial drug discovery: from molecular targets to drug candidates. 1st ed. Weinheim: Wiley-Vch Verlag GmbH and Co. KGaA. 33-432009

15. Adewunmi CO, Agbedahunsi JM, Adebajo AC, et al. Ethno-veterinary medicine: screening of Nigerian medicinal plants for trypanocidal properties. $\mathrm{J}$ Ethnopharmacol 2001;77:19-24.

16. Ogbadoyi EO, Abdulganiy AO, Adama TZ, Okogun JI. In vivo trypanocidal activity of Annona senegalensis Pers. leaf extract against Trypanosoma brucei brucei. J Ethnopharmacol 2007;112:859.

17. Antia RE, Olayemi JO, Aina OO, Ajaiyeoba EO. In vitro and in vivo animal model antitrypanosomal evaluation of ten medicinal plant extracts from South West Nigeria. Afr J Biotechnol
2009;8:1437-40.

18. Aderbauer B, Clausen PH, Kershaw O, Melzig MF. In Vitro and in vivo trypanocidal effect of lipophilic extracts of medicinal plants from Mali And Burkina Faso. J Ethnopharmacol 2008;119:225-31.

19. Tagboto S, Townson S. Antiparasitic properties of medicinal plants and other naturally occurring products. Adv Parasitol 2001;50:199-295.

20. Atawodi SE, Bulus T, Ibrahim S, et al. In vitro trypanocidal effect of methanolic extract of some Nigerian Savannah plants. Afr J Biotechnol 2003;2:312-21.

21. Ibrahim MA, Njoku GC, Sallau AB. In vivo activity of stem bark aqueous extract of Khaya senegalensis against Trypanosoma brucei. Afr J Biotechnol 2008;7:661-3.

22. Luize PS, Tiuman TS, Morello LG, et al. Effects of medicinal plant extracts on growth of Leishmania (L.) amazonensis and Trypanosoma cruzi. Rev Bras Ciênc Farm 2005;41:85-94.

23. Mikail HG. in vitro trypanocidal effect of methanolic extract of Sclerocarya birrea, Commiphora kerstingii and Khaya senegalensis. Afr J Biotechnol 2009;8:2047-9.

24. Peter O, Magiri E, Auma J, et al. Evaluation of in vivo antitrypanosomal activity of selected medicinal plant extracts. J Med Plants Res 2009;3:84954.

25. Morton JF. Pomegranate In: Fruits of warm climates. Centre for New Crops and Plant Products, Purdue University. 1987. pp 352-355. Available from: http://www.hort.purdue.edu/newcrop/m orton/pomegranate.html

26. Choi JG, Kang OH, Lee YS, et al. In vitro and in vivo antibacterial activity of Punica granatum peel ethanol extract against salmonella. Evid Based Complement Alternat Med 2011;2011:690518.

27. Duman AD. Ozgen M, Dayisoylu KS, et al. Antimicrobial Activity of Six Pomegranate (Punica granatum L.) varieties and their relation to some of their pomological and phytonutrient characteristics. Molecules 2009; 14:1808-17.

28. Jurenka J. Therapeutic applications of pomegranate (Punica granatum L.): a review. Altern Med Rev 2008;13:12844.

29. Kim ND, Mehta R, Yu W, et al. Chemopreventive and adjuvant therapeutic potential of pomegranate (Punica granatum) for human breast cancer. Breast Cancer Res Treat 2002;71:20317. 
30. Lansky E, Shubert S, Neeman I. Pharmacological and therapeutic properties of pomegranate. CIHEAM Options Mediterraneennes. 2000;42:231-5.

31. Qnais EY, Elokda AS, Abu Ghalyun YY, Abdulla FA. Antidiarrheal activity of the aqueous extract of Punica granatum (Pomegranate) peels. Pharm Biol 2007;45:715-20.

32. Akhtar MS, Riffat S. Efficacy of Punica granatum, Linn. (Anar) fruit-rinds against naturally acquired nematodal and cestodal infections. J Pharmacy 1985;6:1724.

33. Sharaf A, Fayez MB, Negm SA. Pharmacological properties of Punica granatum L. Plant Foods Hum Nutr 1967;14:331-6.

34. Dell'Agli M, Galli GV, Corbett Y, et al. Antiplasmodial activity of Punica granatum L. fruit rind. J Ethnopharmacol 2009;125 :279-85.

35. Dell'Agli M, Germana VG, Michela B, et al. Ellagitannins of the fruit rind of Pomegranate (Punica granatum) antagonize in vitro the host inflammatory response mechanisms involved in the onset of malaria. Malaria J 2010;9:208.

36. Soh PN, Witkowski B, Olagnier D, et al. In vitro and in vivo properties of ellagic acid in malaria treatment. Antimicrob Agents Chemother 2009;53:1100-16.

37. Bektas N, Ozturk N. Antioxidant activity of Punica granatum (Pomegranate) flowers. Toxicol Lett 2007;172:S62.

38. Barrett SV, Barrett MP. Anti-sleeping sickness drugs and cancer chemotherapy. Parasitol Today 2000;16:7-9.

39. Agrawal SS, Paridhavi M. Herbal drug technology. 2nd ed. Hyderabad: Universities Press Private Limited; 2012.

40. Adamu M, Nwosu CO, Agbede RIS. Anti-trypanosomal effects of aqueous extract of Ocimum gratissimum (Lamiaceae) leaf in rats infected with Trypanosoma bruceibrucei. Afr J Tradit Complement Altern Med 2009;6:262-7.

41. Seiler JP, Long D, Turnheim D, et al. Handbook: good laboratory practice (GLP): quality practices for regulated non-clinical research and development. 2nd ed. Geneva: World Health Organization; 2010. pp 9-57.

42. Committee for the Purpose of Control and Supervision on Experiments on Animals (CPCSEA). CPCSEA guidelines for laboratory animal facility. 2010. Available from: http://envfor.nic.in/divisions/awd/cpcsea_laboratory.pdf

43. Ahmadu Bello University Committee on Animal Use and Care (ABUCAUC). Animal use and care policy. In: Research policy. Ahmadu Bello University Press. 2010. pp. 24-37. Available from: http://www.abu.edu.ng/doc/abu-zariaresearch-policy.pdf

44. Chappuis F, Loutan L, Simarro P, et al.
Options for field diagnosis of human African trypanosomiasis. Clin Microbiol Rev 2005;18:133-46.

45. Herbert WJ, Lumsden WHR. Trypanosoma brucei: a rapid "matching" method for estimating the host's parasitemia. Exp Parasitol 1976;40:427-31.

46. Rosenkranz V, Wink M. Alkaloids induce programmed cell death in bloodstream forms of trypanosomes (Trypanosoma b. brucei). Molecules 2008;13:2462-73.

47. Tasdemir D, Kaiser M, Brun R, et al. Antitrypanosomal and antileishmanial activities of flavonoids and their analogues: in vitro, in vivo, structure-activity relationship, and quantitative structure-activity relationship studies. Antimicrob Agents Chemother 2006;50:1352-64.

48. Nok AJ. Effective measures for controlling trypanosomiasis. Exp Opin Pharmacother 2005;6:1-9.

49. Freiburghaus F, Basel N. African medicinal plant used in the treatment of sleeping sickness - an evaluation. Weittever service Ag Bern 1996:1-23.

50. Maikai VA, Nok JA, Adaudi AO, Alawa CB. In vitro antitrypanosomal activity of aqueous and methanolic crude extracts of stem bark of Ximenia americana on Trypanosoma congolense. J Med Plants Res 2008;2:55-8. 